\title{
腦橋部出血, 一剖檢例
}

\author{
日本整科大學病理學数堂(指皆長澤教授)

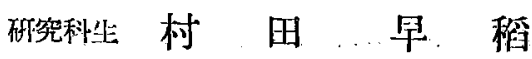

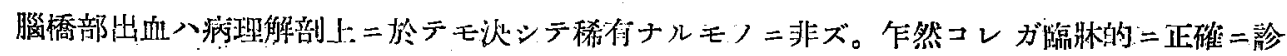

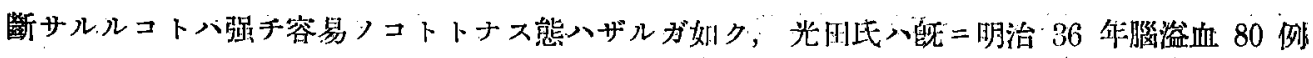

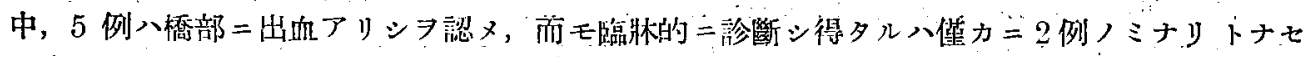
リ。ダナーE八腦出血忠省 50 例中，橋部出血八又僅カ $=3$ 例二過ギズ，比胶的稀ナリ卜提唱

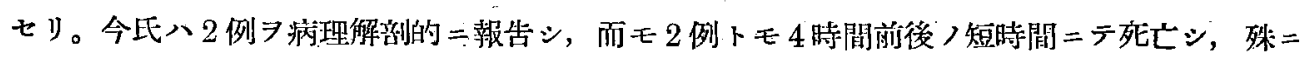

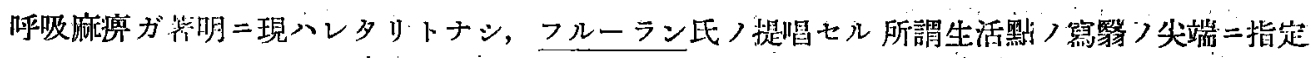

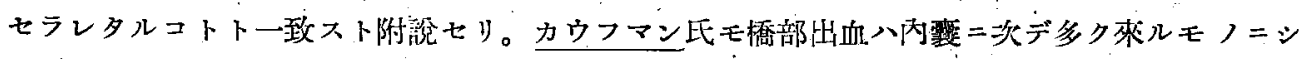

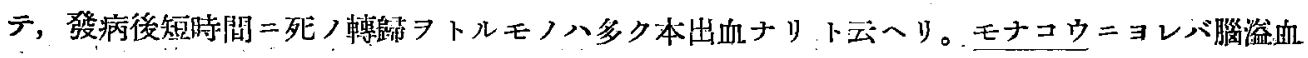
フ $10 \%$ 二本出血八認メラルト，ジュランファルデー八腦溢血 119 例中, 橋部出血八比較的稀 ナリトシ，オッペンイム八橋部出血八內外整二次デ現ハルルモノナリト云へリ。本教室二於

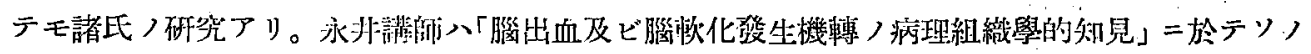

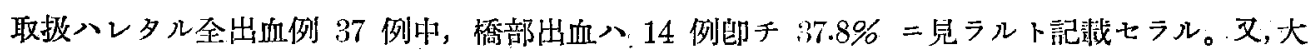

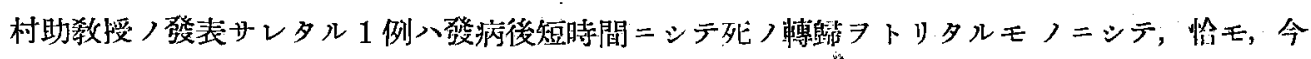

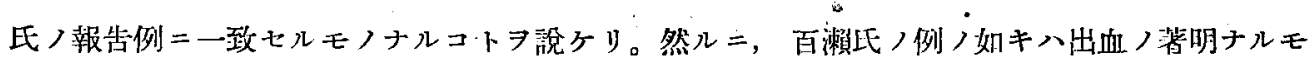
ノニシテ, 而モ發病ヨリ死亡 氏ノ例必ズシモ同一ノ結果ヨ照來セザルモノノ如シ。而シテ竝二余ガ報告セントスルモノ八百

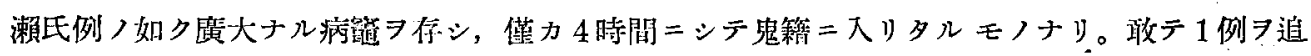
加セムトスル所似ナリ。

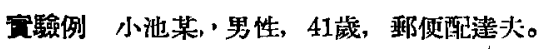

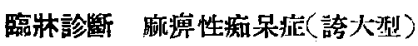

家族歷 祖父湖二就キテ八記述不詳。

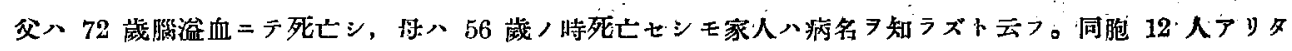

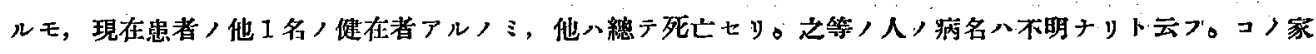

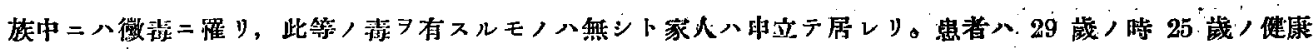

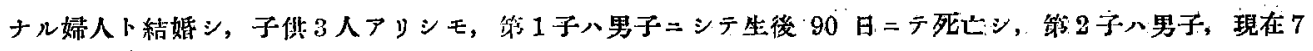

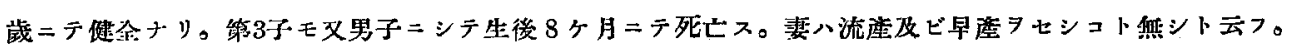

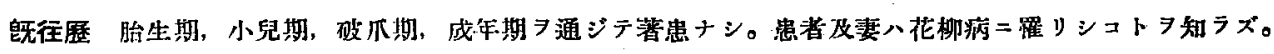
教育程度ハ小學校 $-1181-$ 


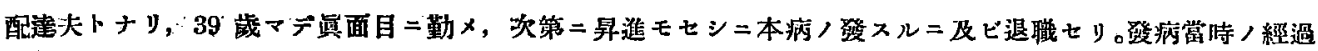

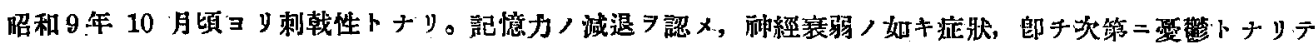

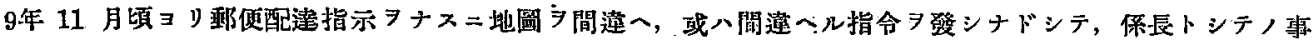

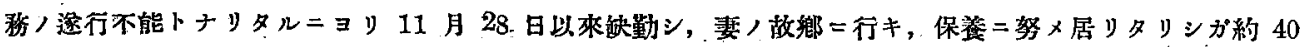

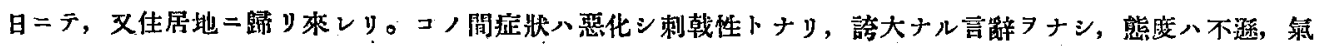

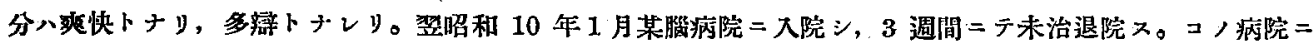
於テ血液檢查ヨ行七シ處，ロッセルマン氏反應，陽性ト判明シ「サルバルサン静脈内注射工回ノミ行七タリ。

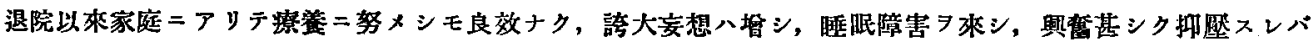

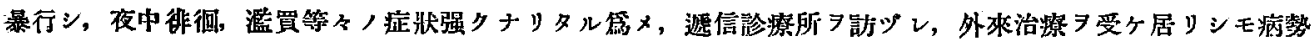

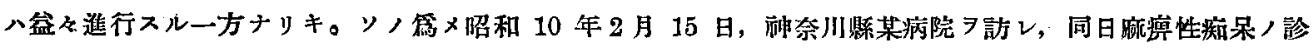

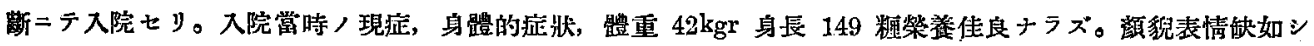

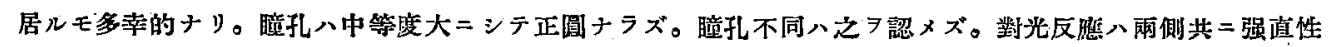

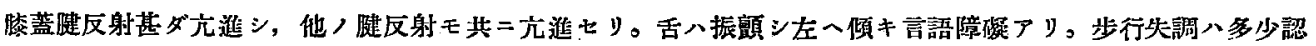

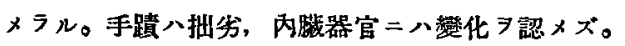

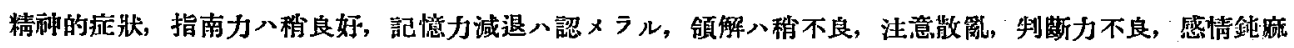

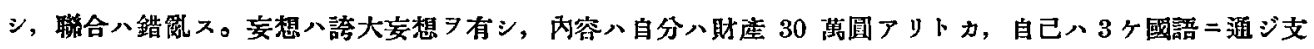

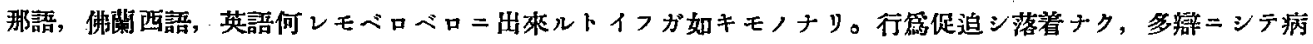
傤ナシ。

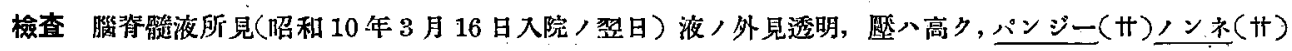

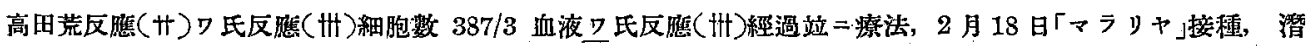
伏期 13 日文過ギ, 3 月 3 日ョリ 3 月 20 日マデ $39^{\circ} 39^{\circ} 3^{\prime} 39^{\circ} 4^{\prime} 38^{\circ} 7^{\prime} 39^{\circ} 1^{\prime} 38^{\circ} 9^{\prime} 39^{\circ} 2^{\prime} 39^{\circ} 5^{\prime} \cdot 39^{\circ} 39^{\circ} 6^{\prime}$

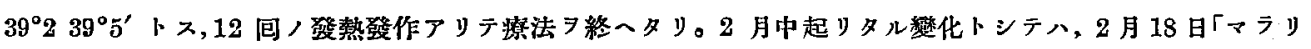

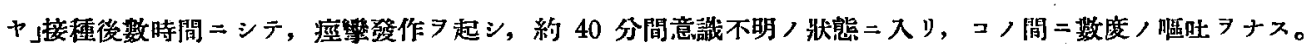
面シテ昍物ハ照褐色，血液

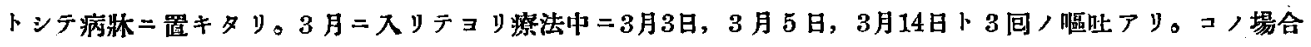

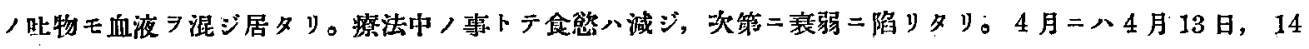

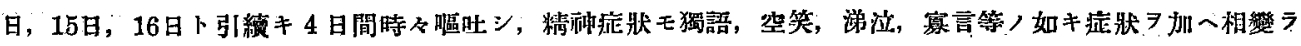

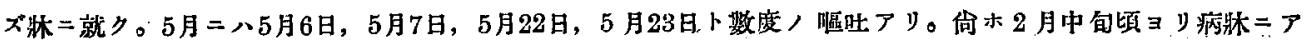

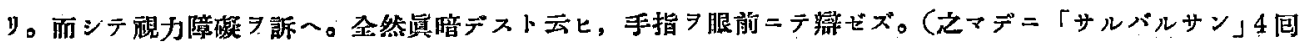

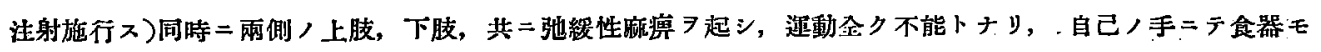

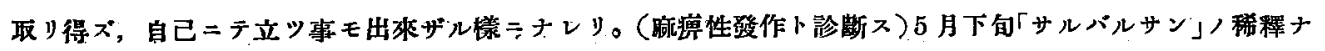

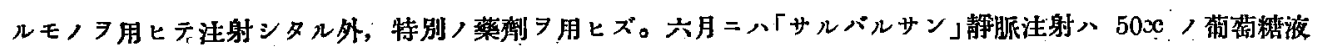

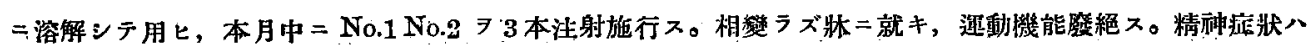

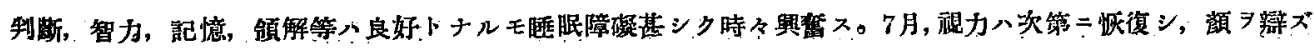

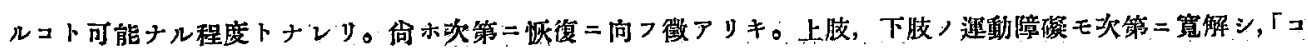




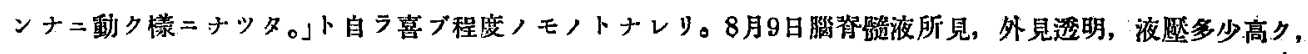

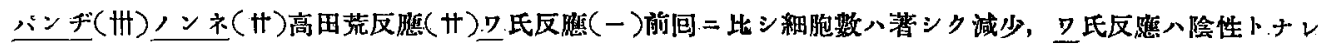

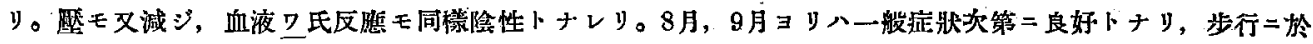

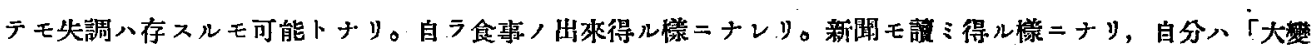

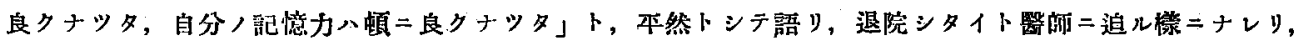

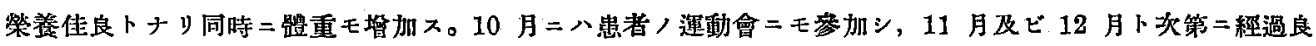

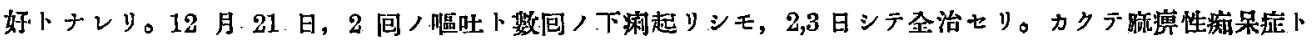
シテノ精神诚状ハ全ク減退シ，且ツ全ク筧解スルニ至レリ。然ルニ昭和 11 年 1 月 14 日年前11時突然卒倒

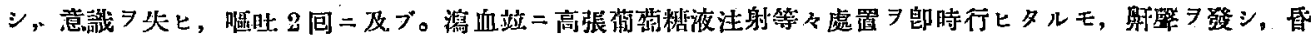
睡ニスり, 次デ呼吸困蜼郎チ落明ナルジャイネストーク氏ノ呼吸現象 入リタリっコノ䦔僅カ $=4$ 洔間ナリキ。

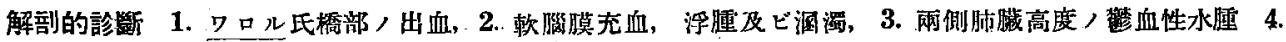

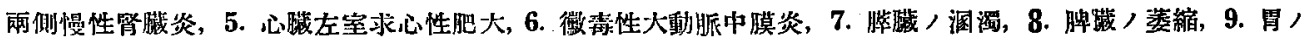

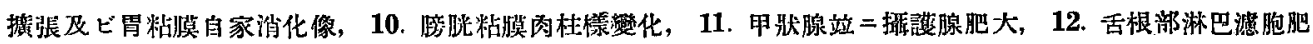

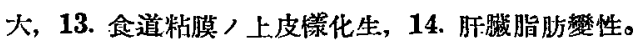

解剖的所胃

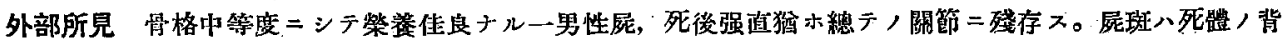

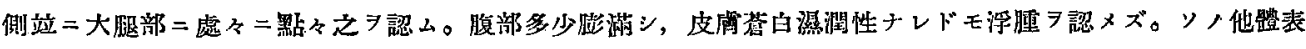

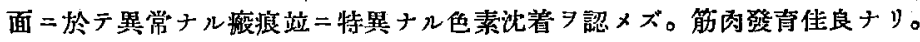

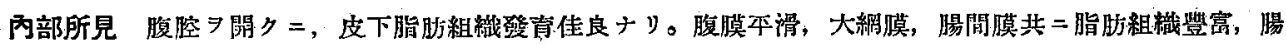

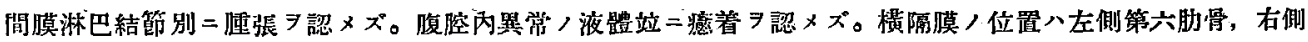
第五肋骨二相管ス。

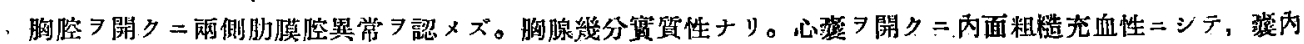
二透明ナル帶蓝色, 液少量

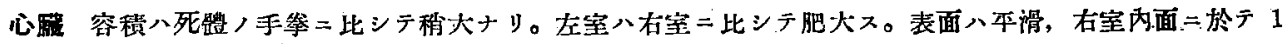

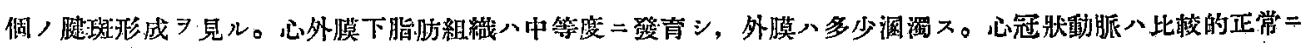
シテ心筋泪濁ス。右心宾 7 開クニ筋質厚ク褐色

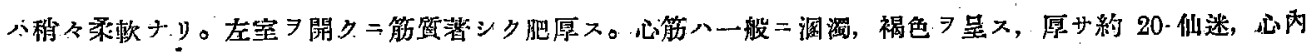

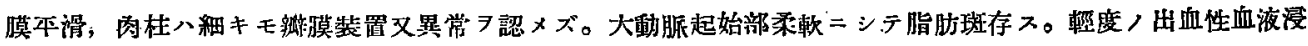
潤 ヨ認么沙異常ナシ。

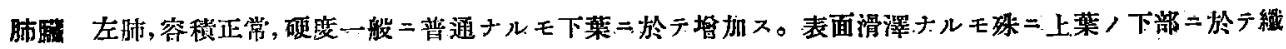

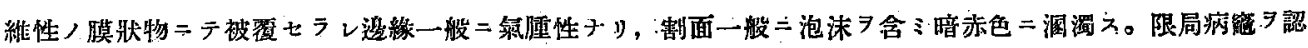

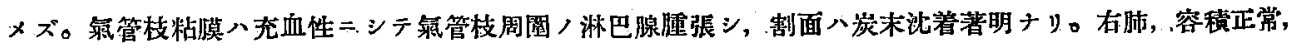

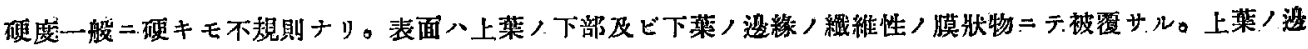

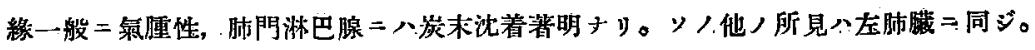


䀒玉 $24.5 \times 17.0 \times 7.0$ 粧, 表面本滑ニシテ硬度ハ幾分㳄カナリ, 右葉八背側ニ於テ僅二痖着スル部アリ。

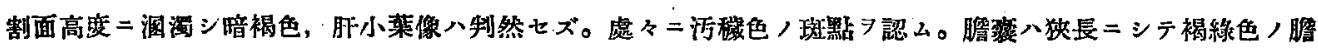
汁 7 会有シ, 粘膜ソ, 他暴常ナシ。

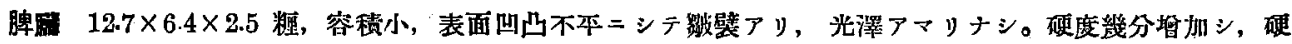

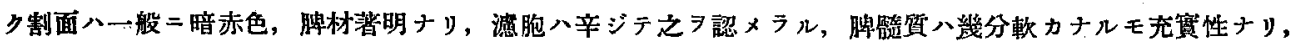

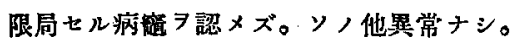

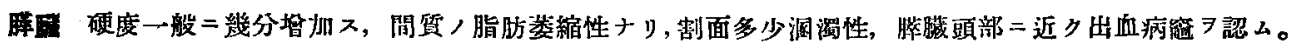

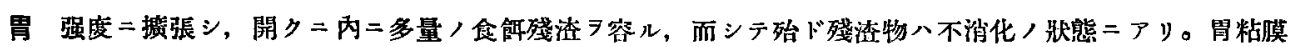

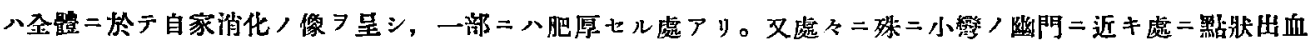

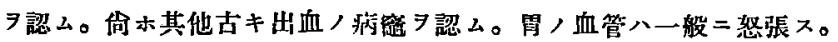

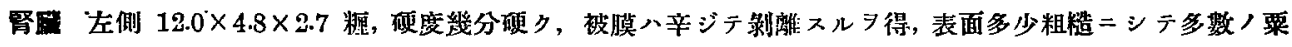

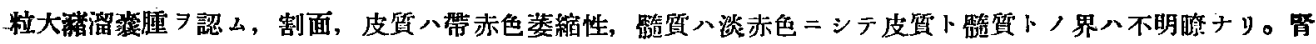

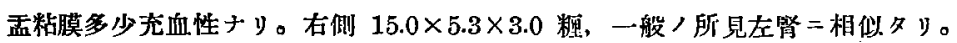

副腎 雨側共二留質稍々肥大性, ソノ他正常ニシテ異常゙ノ所見ナシ。

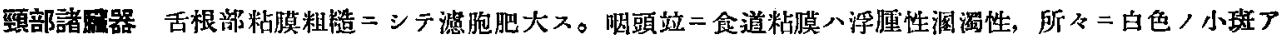

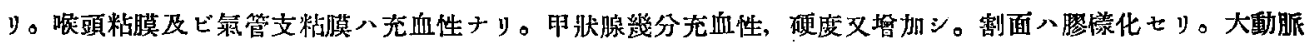

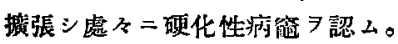

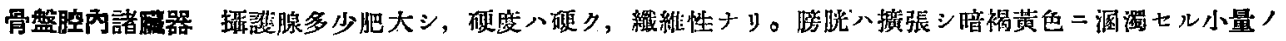
尿 7 有シ，粘膜尤血性，幾分肉桂 7 北成又。又粘膜八不正肥厚 7 呈ス。

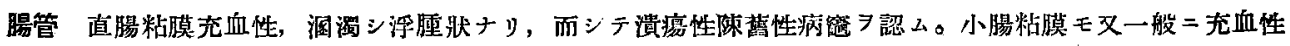
ニシテ洞罯ス。特ニ十二指腸暗ニ於テ著明ナリ。

䨪丸雨側共二肥大シ，割面何レモ充血性ナリ。

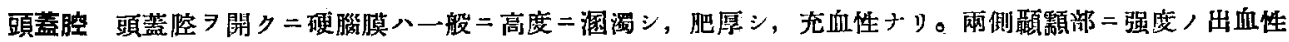

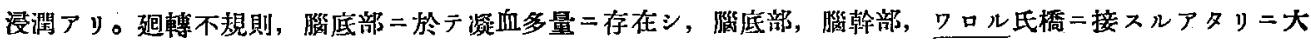

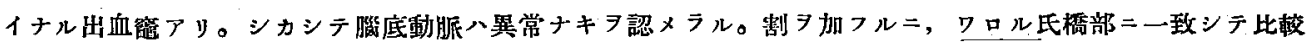

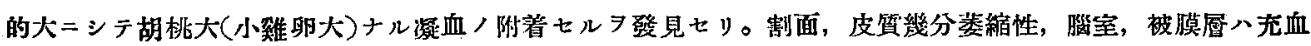
性, 小腦ニハ異常 シ認メズ。

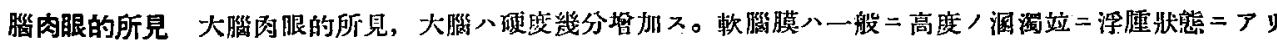

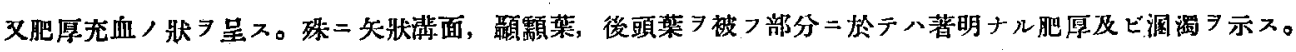

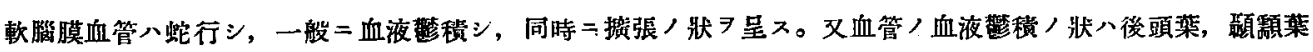

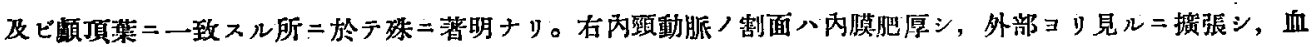

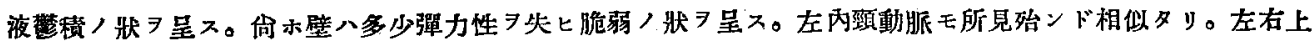

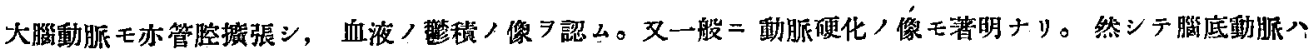

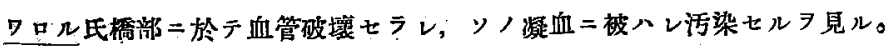

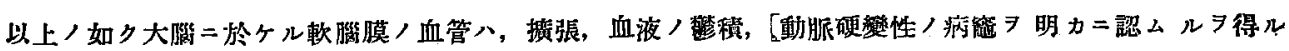


ナリ。

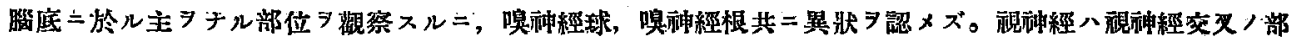

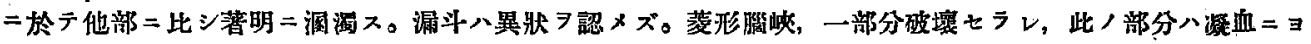

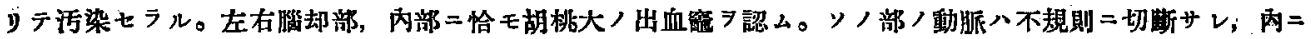

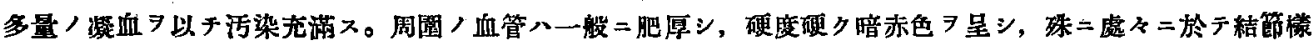

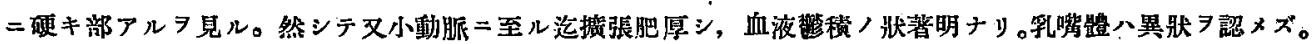

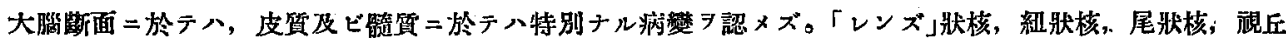

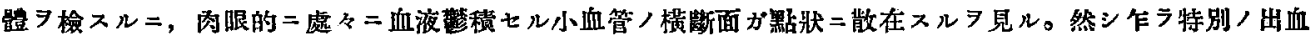

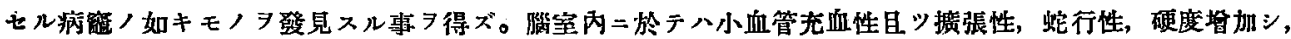

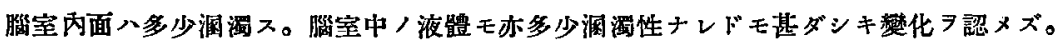

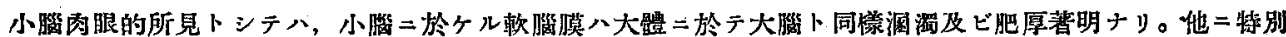

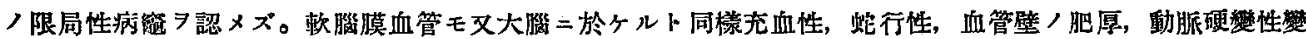

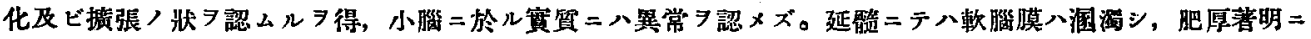

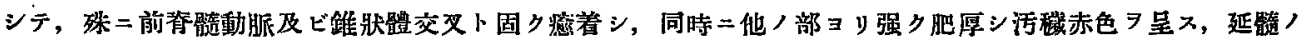

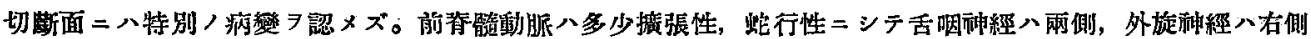

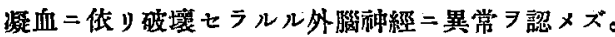

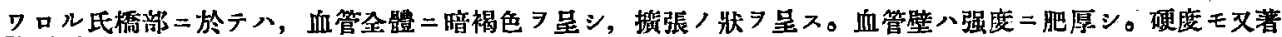
シク热加ス。一部小豆大ノ硬化㘉

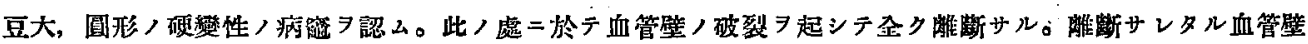

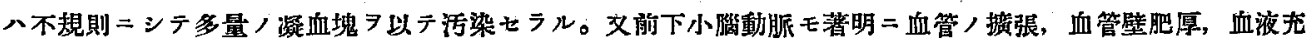

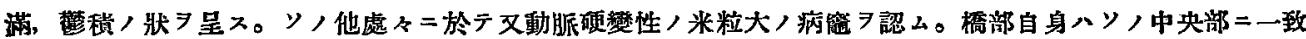

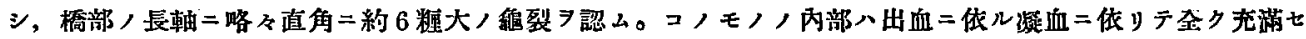

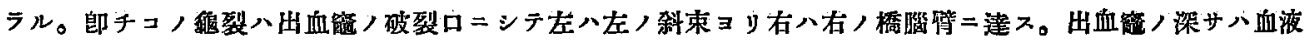

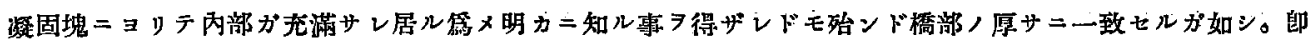

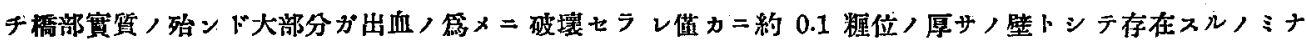

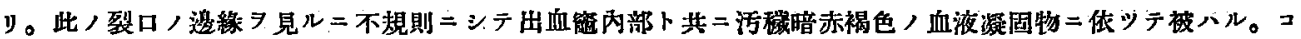

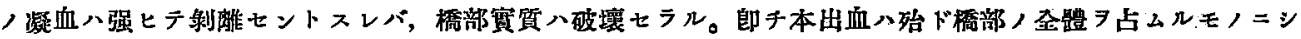
テ，ソ，廣サ恰モ小稓卵大二モ一致スルモノナリ。

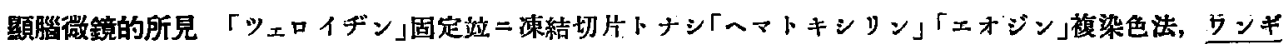

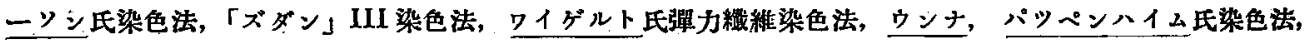

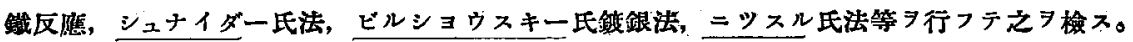

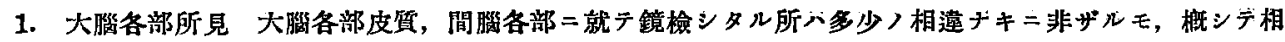

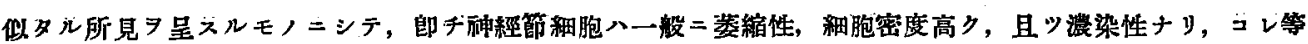

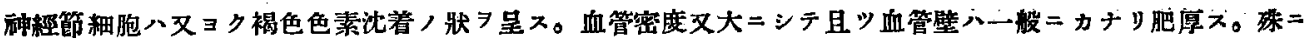

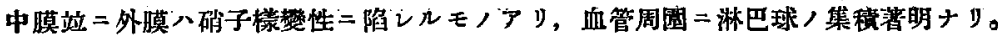




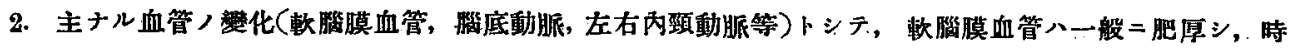

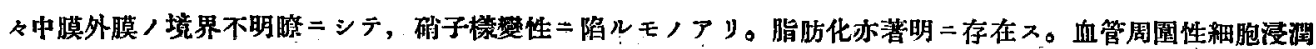
モ盛二認メラル。腦底動脈八高度/動脈哽化像

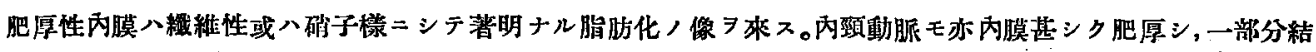
節爿二內腔=向ツテ隆起シ管腔

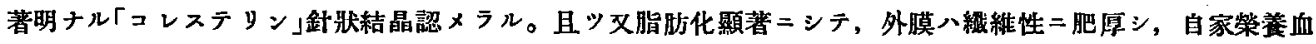
管壁肥厚シ，其周圍ニ八細胞浸潤著明テソ。

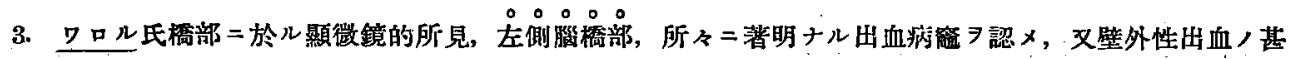

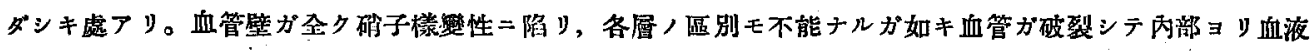

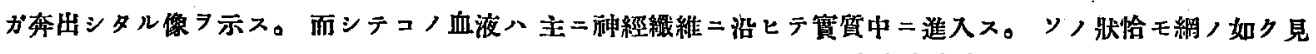

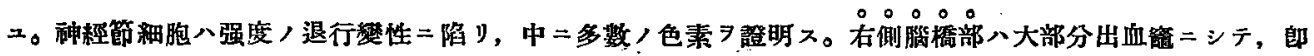

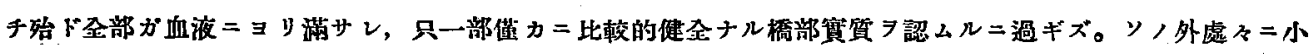

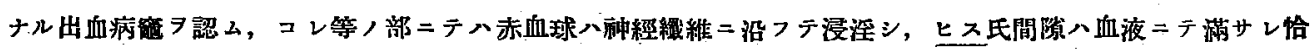

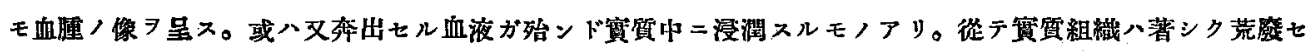

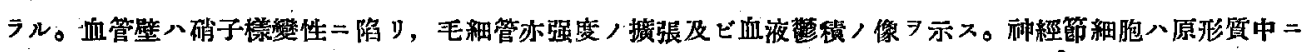

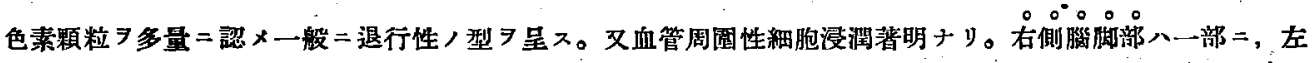

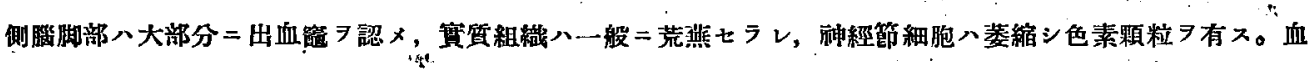
管壁八內膜へ肥厚シテ血液㯱栍ノ像著明ナリ。

\section{總括}

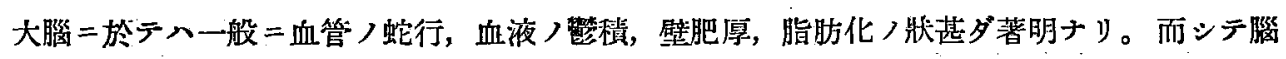

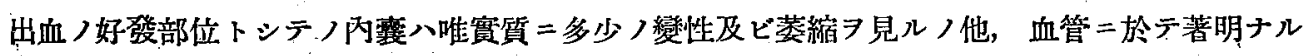
變化フ認メズ。之二反シテ, 左右內頸動脈及ビ腦底動脈八强度つ動脈硬化症, 像 ニアテローム樣變性ヨ認ム。殊二腦底動脈ノ上下大腦動脈トノ分岐點ニ於テハ特二著明ナル動 脈硬化症像 $コ$ 呈シ, コノ所二於テ大破裂フ起シタルモノナリ。

ワロル氏橋部基質八张出七ル血液二壓迫七ラレ, 种經細胞ノ大部分八變性二陷リ，或八萎縮 ノ狀シ示ス。凡テ大腦皮質二此シ病變著明ナリ。而シテ內霆ノ如キ好發部位二大出血來ラズシ

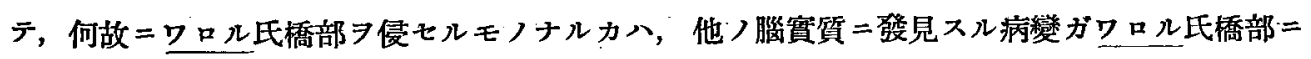
此シテ輕度ナルコト，之二反シテワロル氏橋部八肉眼的二モ顯微鏡的二モ著明ナル動脈硬化像

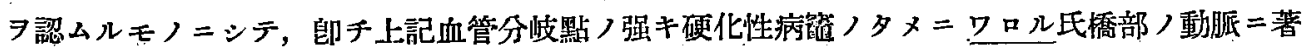
シキ强キ血行障礙ト，ソレ二因スル處ノ側枝性允血等 化甚シキ部ノ腦底動脈分岐點ノ血管:於テ破裂大出血シ起七ルモノナラン。

又本例/如ク極メテ短時間二於テ死セルコトハ, 已二諸家ノ症例＝明カナル如ク，所謂フル こラン氏ノ生活點ガ侵サレシ篇メナルベタ, 從デ, 大村, 今, カウフマン等墸氏，例 $=1$ 例 追加シ得ルモノナリ。カクシテ本例ノ大出血 ヨ起シタ几原因八, 之符動胍硬化性病變二求ムル 


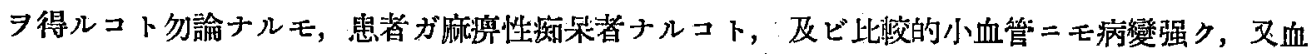

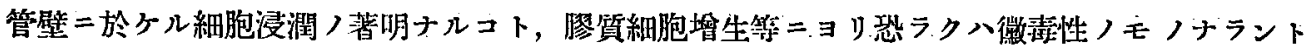
思考ス。

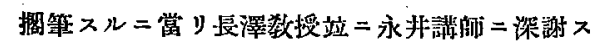

附圆說明

第 1 圖 橋部出血埴 7 切斷面ヨリ見ル。

第 2 圖 變性ヨ起セル血管壁ノ破綻性出血 7 思ハシム。

第 3 圖 病䆚附近〉血管套狀出血

第 4 圖 出血襍八毛細管性出血)集合ヨリナル。

\section{主用 文 獻}

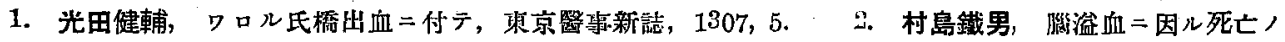

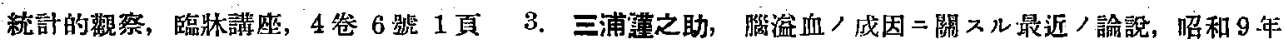

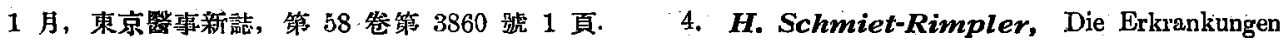
des Auges im Zusammenhnag mit anderen Krankheiten. Wien 1905 II Auflage S. 167 . 5. A. Strumpell, Specielle Pathologie und Therapie 22 Auflage II Band S. 708. 6. 住友次郎, 小林進 稀有ナ

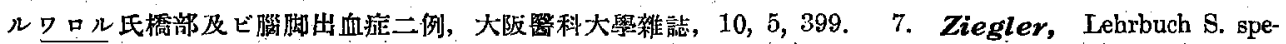
cieller pathol. Anatomie 1892. S. 345-346. S. 4101906 etc 13. 8. Spalteholz, Handatlas des Menschen. LIl. Band. S. 644 S. 705. 9. Rauber, Kopsch, Lehrbuch d. Anatomie IX Auflage, V. Band. S. 214 S. 221. 10. Ph. Stährs, Lehrbuch der Histologie 18. Band. S. 201. 211. 11. 大村清二,

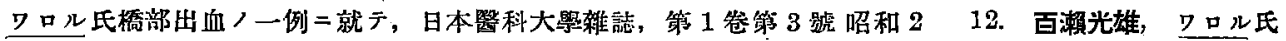

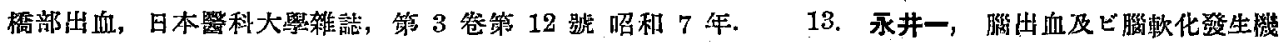

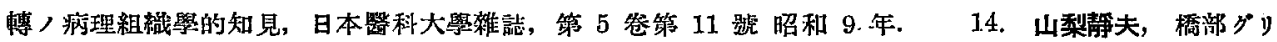

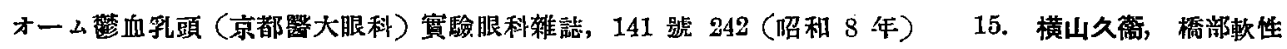

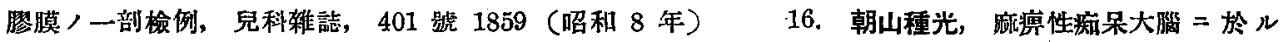

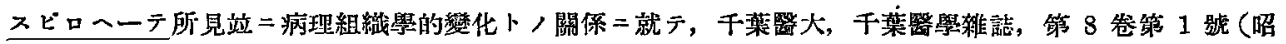

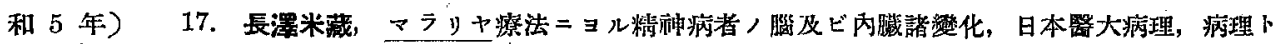

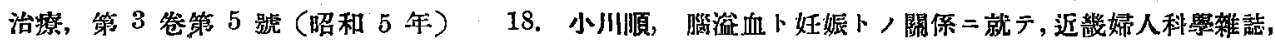
第 14 卷第 1 號 233 頁. 19. 田村利雄, 高血摩病卜動脈硬化痕, 炤和 5 年肘. 20. Dana, Bulbar paralysis etc med Rundschau 64. 1903. S. 361. 21. Ernst, Pathologische Anatomie von L. Aschoff 5. auflage 11 Band Speiziller teil. 22. 速見猛, 病理學總諭, 上缭, 下卷. 23. Kaufman,

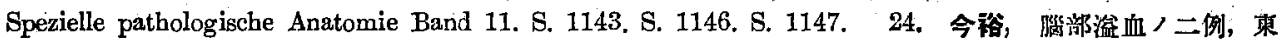
京醫事新誌, 1852, 1. 25. “今浴, “新鹳病理學各論. 26. M. Lowandousky, Handbush d. Neuro-

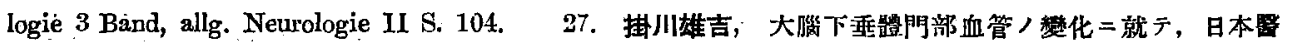
科大學雜誌, 第 7 卷第 4 號 349 . 
村田論文附圖

\section{第 一 圖}

第三圖

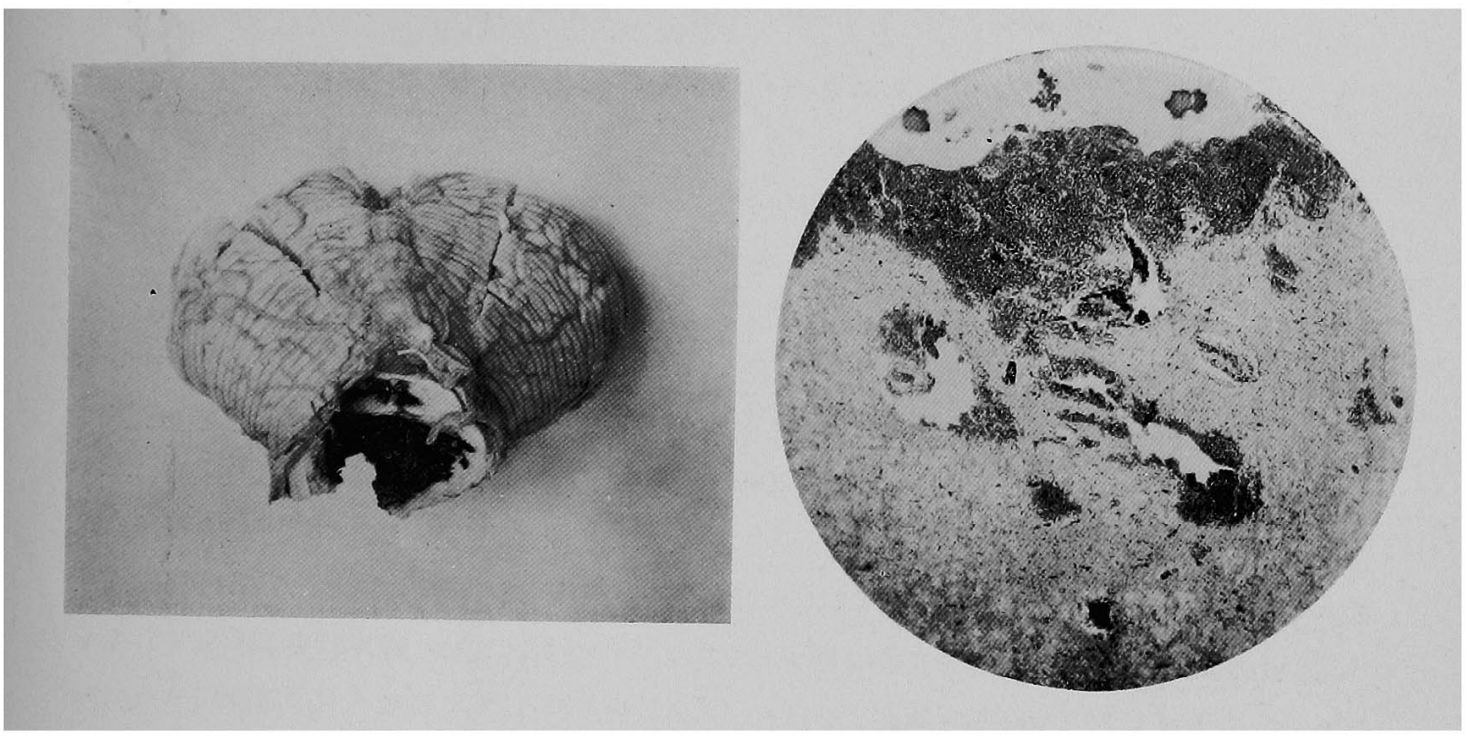

第二 圖

第 四 圖

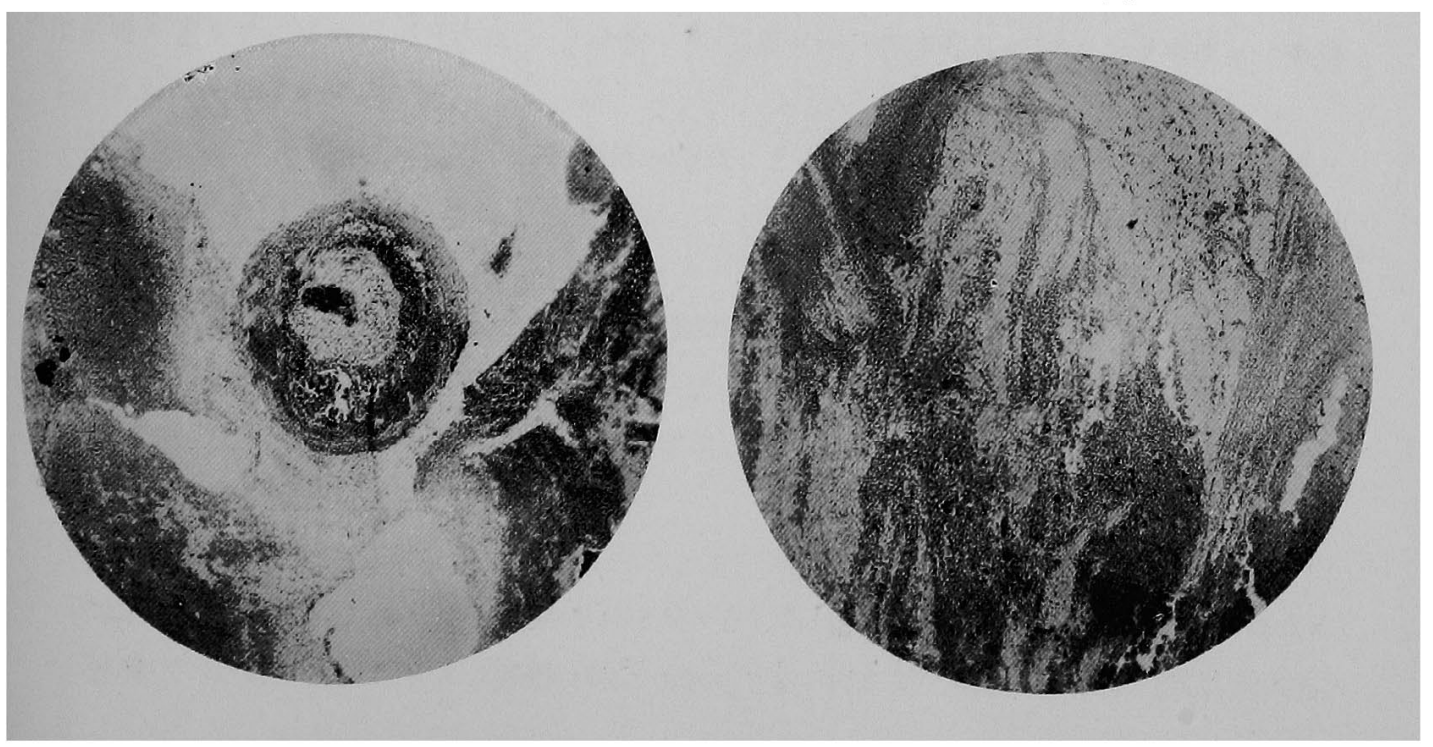

